\title{
Mandatory trialling of support services by international students: What they choose and how they reflect
}

Ben Fenton-Smith, Griffith University, School of Languages and Linguistics

Rowan Michael, Griffith University, School of Languages and Linguistics

\section{Corresponding author:}

Ben Fenton-Smith: benfento@gmail.com

\begin{abstract}
This paper evaluates a strategy to promote uptake of support services by international students (ISs) at an Australian university. As part of their assessment ISs completed a so-called 'University Service Reflection Task' (USRT) in a core first year course. To complete the USRT all ISs accessed one support service (e.g. language consultation, study skills workshop, careers guidance), then submitted a written reflection about the experience. Using responses to a questionnaire by 155 participants, the researchers investigated which services ISs attended for the USRT and patterns of prior attendance. Students' perspectives were explored by analysing 73 reflective essays. The results showed that two-thirds of the students participated in a service for the first time in order to complete the USRT and favoured services that had closest application to their coursework. Students expressed positive feelings about their experiences and reported learning gains, particularly in the areas of study skills and development of academic language.
\end{abstract}

\section{Keywords}

international students, support, academic language and learning, reflection, study skills, socialization 


\section{Introduction}

The language proficiency and academic capabilities of international students (ISs) at Australian universities has been scrutinised by academics (e.g. Birrell 2006; Benzie 2010), government departments (e.g. DEEWR 2009; AEI 2010a) and national media (e.g. Ewart 2007; Healy and Trounson 2010) in recent years. Although universities operate numerous support services to aid ISs in the areas of information literacy, study skills, language enhancement, cultural adjustment, counselling, and career development, the extent to which students know about and utilise the services is questionable. Rochecouste et al. $(2010,20)$ state that 'despite the time and effort that has been invested in language and learning support for international students in Australian universities ... it seems that, for a number of reasons, many students avoid or are unable to use such services'. This conclusion is echoed in multiple studies, including Astin (1996), Prebble et al. (2004), Barrett-Lennard and Bulsara (2007), and Stallman (2011).

This paper describes one attempt to address the issue by requiring undergraduate ISs enrolled in a compulsory first year course to complete an assignment, as part of assessment, titled the 'University Service Reflection Task' (USRT). The students' instructions were to select and access a support service from a prescribed list (e.g. language consultation, study skills workshop, careers guidance) and prepare a written reflection on the experience. We report on the results of the initiative both in terms of the 'what, where, and how often' of service uptake, and on the deeper qualitative issues raised in the students' written reflections. Although the focus of the paper is ISs, it is not suggested that those students alone are in need of developmental support: all students could benefit from it. 


\section{Support services for international students in higher education and the USRT}

The literature on ISs from non-English speaking backgrounds (NESBs) studying in English-medium universities points to several types of necessary support. The first type is learning support. Experts on English for academic purposes (EAP), such as Hyland (2006), state that students benefit from both general study skills support and academic literacy support. The former refers to generic competencies, such as referencing and using the library. The latter is language-focused, referring to the mastery of discipline-specific language forms (from sentence level to whole texts), as well as to the ways different academic disciplines express their 'culture' (norms, power structures, knowledge beliefs, etc.). Another issue is social support, with many studies establishing the link between social connectedness and academic success (Saenz et al. 1999; Peat, Dalziel and Grant 2001; Prebble et al. 2004; Walsh 2010; Gersham and Clayton 2011). In Australia, the desire of ISs to be less socially isolated - especially on campus - is well documented (AEI 2010b; Marginson et al. 2010). ISs also require support to boost their employability: for example, research by Australian Education International showed that $69 \%$ of employers 'were concerned about the standard of written and spoken English of Australian educated international graduates' (2010a, 16). While many ISs may return to their home country upon graduation and some may never use English again, the onus remains on universities to prepare all such students for the possibilities of both local employment requiring English and globally oriented employment on home soil in which English is used as a lingua franca.

It is evident that the USRT was designed with a holistic view of support in mind. Academic achievement, communicative competence, personal wellbeing, and professional aspiration were considered equally worthy of attention. Thus, for example, university clubs were considered a type of 'support service' since they offer opportunities to make friends and improve English. The following is a list of services that were included in the assignment 
(note that counselling was omitted due to its personal nature):

\begin{tabular}{|c|c|c|c|}
\hline Service name & Service description & Availability & Orientation \\
\hline $\begin{array}{l}\text { Library Learning } \\
\text { Services }\end{array}$ & $\begin{array}{l}\text { Workshops on } \\
\text { information literacy, } \\
\text { academic skills and } \\
\text { computer skills. }\end{array}$ & $\begin{array}{l}\text { 10-15 different } \\
\text { workshops each week, } \\
\text { during semester (less } \\
\text { towards end of } \\
\text { semester). Limited } \\
\text { places - requires } \\
\text { booking. }\end{array}$ & Scholastic \\
\hline English HELP & $\begin{array}{l}\text { One-to-one tutoring for } \\
\text { language assistance. }\end{array}$ & $\begin{array}{l}\text { Runs all year, but less } \\
\text { frequent outside } \\
\text { semester. Only for ISs } \\
\text { or domestic NESB } \\
\text { students. Only one 45- } \\
\text { minute consultation } \\
\text { per week allowed. }\end{array}$ & Linguistic \\
\hline Find Your Voice & $\begin{array}{l}\text { A series of workshops } \\
\text { on cross-cultural } \\
\text { communication. }\end{array}$ & $\begin{array}{l}\text { One workshop per } \\
\text { week during semester. } \\
\text { Unlimited access for } \\
\text { all students. }\end{array}$ & $\begin{array}{l}\text { Linguistic and } \\
\text { cultural }\end{array}$ \\
\hline Student Linx & $\begin{array}{l}\text { Cross-cultural student } \\
\text { socialization service. }\end{array}$ & $\begin{array}{l}\text { Multiple activities run } \\
\text { all semester, with }\end{array}$ & Social \\
\hline
\end{tabular}




\begin{tabular}{|c|c|c|c|}
\hline & $\begin{array}{l}\text { Activities include } \\
\text { organized games, } \\
\text { parties and social } \\
\text { outings. }\end{array}$ & $\begin{array}{l}\text { unlimited access for } \\
\text { all students. }\end{array}$ & \\
\hline Clubs & $\begin{array}{l}\text { Educational, } \\
\text { professional, sporting, } \\
\text { political, religious, } \\
\text { cultural, and special } \\
\text { interest clubs are } \\
\text { available. }\end{array}$ & $\begin{array}{l}\text { Any student can join a } \\
\text { club at any time by } \\
\text { contacting a club } \\
\text { convenor through the } \\
\text { university's clubs } \\
\text { website, or by signing } \\
\text { up on orientation } \\
\text { days. }\end{array}$ & Social \\
\hline $\begin{array}{l}\text { Careers and } \\
\text { Employment }\end{array}$ & $\begin{array}{l}\text { A service designed to } \\
\text { assist students in } \\
\text { gaining employment. }\end{array}$ & $\begin{array}{l}\text { 20-minute individual } \\
\text { consultations and } \\
\text { targeted seminars are } \\
\text { offered year-round. } \\
\text { Unlimited access for } \\
\text { all students. }\end{array}$ & Professional \\
\hline
\end{tabular}

Table 1. Services students could choose from.

In addition to participating in one of the above services, the USRT also involved writing a structured reflection about the experience. The next section provides a theoretical basis for this reflective aspect. 


\section{Reflective writing in higher education and the USRT}

One of the theoretical underpinnings of the USRT was the idea that meaningful reflection can be triggered by challenging situations. This view is associated with Dewey, who noted that ' $[\mathrm{a}] \mathrm{s}$ long as our activity glides smoothly along from one thing to another ... there is no call for reflection'; what is required is 'a forked road situation, a situation which is ambiguous, which presents a dilemma, which proposes alternatives' $(1910,11)$. Since Dewey, the problem-based model of reflective practice has been widely applied in education. Rogers notes in his concept analysis of reflection in higher education that most authors posit 'an event or situation beyond the individual's typical experience' $(2001,42)$ as a necessary antecedent to reflection. Essentially this is what the USRT is - an atypical experience for many students who would not normally access a support service.

Many methods have been proposed for fostering reflection, including questioning (Seibert and Daudelin 1999), group discussions (Loughran 1999), and reflective journals (Kember et al. 1999, 2008; Moon 2006; Bell et al. 2011; Clarkeburn and Kettula 2011; Dyment and O'Connell 2011). Writing was the most commonly documented activity in the literature on reflection in higher education and was therefore incorporated into the USRT. Reflective texts were viewed as an effective way of encouraging students to externalize their thoughts and to develop an awareness of their unconscious beliefs, premises and habits (Boud, Keogh, and Walker 1985; Rogers 2001).

Written reflections are not without drawbacks, however. Hatton and Smith (1995) question whether sufficient evidence exists to show that such texts do in fact engender reflection. Macfarlane and Gourlay (2009) bemoan the 'behavioural conformism' engendered by reflective writing in teacher education, where instead of reflecting, students may merely 
follow whichever belief systems are in vogue amongst the powers-that-be. For this reason, our students were encouraged to voice both negative and positive appraisals of their service experience. Dyment and O'Connell (2011) argue that educators too often assign students reflective writing tasks without sufficient training or structure. We therefore provided detailed assignment instructions for the USRT. The biggest controversy surrounds assessment: some (e.g. Kember et al. 2008) argue that if a course places value on reflection, the reflection should be assessed, while others (e.g. Ixer 1999, Bell et al. 2011) question the ethics of assessing personal writing. Many authors (Kember et al. 1999, 2008; Stewart and Richardson 2000; Bell et al. 2011; Clarkeburn and Kettula 2011, Ryan 2011; Smith 2011) debate whether a valid and reliable assessment mechanism is at all possible. In recognition of this debate, formative assessment was favoured over summative for the USRT.

\section{Institutional context}

Griffith University is a large comprehensive Australian university with five campuses in south-east Queensland. It has a student population of 43 000, of whom approximately 23\% are ISs. The USRT was undertaken within the university's program of English Language Enhancement Courses (ELECs): four full-credit subjects intended to boost the oral and written English language proficiency of ISs and give them the skills to succeed throughout their degree. Each course is aligned with one of the university's major academic groupings:

- English Language and Communication for Business and Commerce

- English Language and Communication for Health

- English Language and Communication for Science, Environment, Engineering and Technology

- English Language and Communication for Arts and Social Sciences 
All ISs enrolled at Griffith are required to take an ELEC as part of their degree (preferably in the first semester of the first year), unless they are exempted by having met certain criteria (for details, see http://www.griffith.edu.au/international/english-enhancement-course). Each course runs for one 13-week term, with a 2-hour lecture and a 2-hour tutorial per week. In the semester in which the present study was conducted, 851 students were enrolled in the ELEC program.

\section{The University Service Reflection Task}

The USRT requires students to investigate the range of learning opportunities available at university; then access at least one; and submit a written reflection on the experience. Instructions for attending the services and writing the reflection are explained in an instruction sheet (Appendix 1), in line with recommendations from the literature (summarised above) that a lack of structure can lead to unfocussed reflection. Also as mentioned previously, since summative assessment is problematic in reflective writing, a numerical grade is not awarded for the reflective essay. Instead, a formative comment is provided and marks for the course reduced only in the case of non-submission. This allows students to reflect frankly on their service experience.

The USRT rationale is threefold:

(1) Ensure that ISs are oriented to support activities at the beginning of their degree.

(2) Ensure that ISs attend at least one service.

(3) Encourage ISs' ongoing self-development.

The paradox of promoting self-development via a compulsory assignment within a compulsory course is acknowledged. However, as Smith $(2008,396)$ has indicated, the notion 
of targeted training is not alien to learner autonomy:

There persists a tension $\ldots$ between pedagogical approaches which construe autonomy primarily as something learners lack and so need to be 'trained towards' and those which take as a starting point the idea that learners - of whatever background culture - are already able, at least to some degree, to exercise control over their own learning.

Implementation of the USRT acknowledges that some element of training is appropriate in the early stages of degree programs so that self-initiated actions can subsequently take place.

\section{Research questions}

Specifically, this paper reports on the outcomes of implementing the USRT and answers the following questions:

(1) Which university services did students access for the USRT?

(2) Did the USRT lead to first-time service access?

(3) How often had repeat users accessed their chosen services?

(4) Did the writing task stimulate meaningful reflection?

\section{Methodology}

\section{Questionnaire}

An anonymous and voluntary paper-based questionnaire (Appendix 2) was offered to all students who attended ELEC lectures over a one-week period. Students were assured via an ethical consent document that their grades would not be affected. In total, 226 questionnaires were collected. After removing invalid responses and those lacking ethical consent, the number of questionnaires was reduced to 155 , representing $18.2 \%$ of the 851 
ELEC students enrolled in that semester. The written responses were entered into an Excel spreadsheet and then analysed to answer research questions 1-3.

\section{Text analysis}

Hard copies of 73 written reflections were obtained (with ethical consent) from a sample of tutorial groups within the business and health strands of the ELECs, representing the work of $8.6 \%$ of all ELEC students in that semester. The texts were transcribed into a set of discrete Word files, which were in turn collated within an NVivo 9 project file. NVivo 9 is one type of computer-assisted qualitative data analysis software (CAQDAS). As Sinkovics and Alfoldi $(2012,839)$ have stated, CAQDAS does not 'eliminate the inherently 'messy' nature of qualitative research', it simply makes 'the analysis of large volumes of data more manageable and transparent, through systematic comparison and record-keeping'. Thus, the two researchers coded the texts digitally, identifying key themes across the corpus. An advantage of this approach is that NVivo 9 could then be used to report 'text coverage statistics' whereby the amount of text a given theme covered in the corpus could be stated in percentage terms. The other way in which themes were quantified was by the number of texts they appeared in. In reporting the findings, all names were substituted for pseudonyms and students' grammatical errors were not corrected.

\section{Results}

\section{Services accessed by students (RQ1)}

The most basic function of the questionnaire was to find out which services students used to complete the USRT. The findings are presented in 


\begin{tabular}{|c|c|c|}
\hline & $\begin{array}{c}\text { Number of } \\
\text { students }\end{array}$ & Percentage \\
\hline English HELP & 76 & 49.0 \\
\hline Library-learning services & 45 & 29.0 \\
\hline Student Linx & 13 & 8.4 \\
\hline Find Your Voice & 8 & 5.2 \\
\hline Careers and employment & 6 & 3.9 \\
\hline Clubs & 6 & 3.9 \\
\hline Didn't do the activity & 1 & 0.6 \\
\hline Total & 155 & 100.0 \\
\hline
\end{tabular}

Table 2.

\begin{tabular}{|l|c|c|}
\hline & Number of & Percentage \\
\hline English HELP & 76 & 49.0 \\
\hline Library-learning services & 45 & 29.0 \\
\hline Student Linx & 13 & 8.4 \\
\hline Find Your Voice & 8 & 5.2 \\
\hline
\end{tabular}




\begin{tabular}{|c|c|c|}
\hline Careers and employment & 6 & 3.9 \\
\hline Clubs & 6 & 3.9 \\
\hline Didn't do the activity & 1 & 0.6 \\
\hline Total & 155 & 100.0 \\
\hline
\end{tabular}

Table 2. University services accessed.

Of the 155 respondents, almost half (49\%) accessed one-to-one consultations to discuss language issues (English HELP), and nearly one-third (29\%) attended a library learning service. There were significantly fewer participants for the two services offering social interaction: only $8.4 \%$ selected Student Linx and only $3.9 \%$ chose a university club.

\section{First time vs. repeat access (RQ2)}

A second purpose of the questionnaire was to find out whether students would use the USRT to attend a service they were already familiar with (one they had attended before), or whether it would motivate them to try something new (attend a service for the first time). Nearly two-thirds $(62.6 \%)$ of respondents indicated that they accessed the service for the first time while just over one-third (37.4\%) indicated they had used the service previously (this latter group is termed 'repeat users' in this paper).

\section{Repeat users: regularity of access (RQ3)}

The third questionnaire item asked repeat users how often they had used their chosen 
service prior to this assignment.

\begin{tabular}{|c|c|c|}
\hline & Number of students & Percentage \\
\hline Didn't answer & 4 & 6.9 \\
\hline 1-2 times & 14 & 24.1 \\
\hline 3-5 times & 24 & 41.4 \\
\hline 5-9 times & 7 & 12.1 \\
\hline $10+$ times & 9 & 15.5 \\
\hline Total & 58 & 100 \\
\hline
\end{tabular}

Table 3 presents the results:

\begin{tabular}{|c|c|c|}
\hline & Number of students & Percentage \\
\hline Didn't answer & 4 & 6.9 \\
\hline 1-2 times & 14 & 24.1 \\
\hline 3-5 times & 24 & 41.4 \\
\hline $5-9$ times & 7 & 12.1 \\
\hline $10+$ times & 9 & 15.5 \\
\hline Total & 58 & 100 \\
\hline
\end{tabular}

Table 3. Number of times repeat users have attended services. 
Approximately one-quarter $(24.1 \%)$ indicated they had only attended the service one or two times previously. A large number (41.4\%) indicated they had attended 3-5 times. Several respondents seemed to have accessed their chosen activity many times previously, with $12.1 \%$ answering 5-9 times and $15.5 \%$ answering 10 or more times.

\section{The writing task (RQ 4)}

As mentioned above, 73 reflective essays were obtained from a sample of tutorial groups. The services written about in these texts broadly represented the services reported in the questionnaire, in that the majority were reflections on either English HELP $(n=33)$ or Library Learning Services $(n=28)$, with a much smaller representation of the other services. In terms of how students wrote about the services, five main types of writing emerged in the analysis (see Table 4).

\begin{tabular}{|l|c|c|}
\hline Type of writing & Number of texts & Text coverage \% \\
\hline Description of the service experience & 73 & 38.5 \\
\hline Evaluation of the service experience & 73 & 36.9 \\
\hline Statements about learning gains & 72 & 31.7 \\
\hline Explanation of reason(s) for choosing the service & 73 & 17.6 \\
\hline Statements of personal identity & 57 & 8.7 \\
\hline
\end{tabular}


Note: 'Number of texts' refers to the number of reflective essays in which the types of writing appeared; 'Text coverage \%' indicates the percentage of the total corpus that was devoted to each type.

Table 4. How students wrote about the services.

A fuller explanation of each of these major themes is provided in the sections that follow.

Description of the service experience

Every text contained descriptions of the service experience, as directed by the assignment instructions. Three aspects were described: content, procedure and purpose.

\begin{tabular}{|l|c|c|}
\hline \multicolumn{1}{|c|}{ Function of } & $\begin{array}{c}\text { Number of } \\
\text { texts }\end{array}$ & Text \\
description & 71 & 25.8 \\
\hline Describe service content & 64 & 10.7 \\
\hline Describe service procedure & 26 & 3.5 \\
\hline Describe service purpose & 26 & \\
\hline
\end{tabular}

Table 5 shows the prevalence of each sub-type:

\begin{tabular}{|l|c|c|}
\hline Function of description & Number of & Text \\
texts & coverage \% \\
\hline Describe service content & 71 & 25.8 \\
\hline
\end{tabular}




\begin{tabular}{|l|c|c|}
\hline Describe service procedure & 64 & 10.7 \\
\hline Describe service purpose & 26 & 3.5 \\
\hline
\end{tabular}

Table 5. Three functions of descriptive language in the reflective essays.

Content description was the most common, covering one quarter of the corpus, and observed in all but two texts. This is where students recounted the 'goings on' of the service experience, as in this example:

First, the teacher introduced the main structures of report and essay to me that I can distinguish them. Then, she told me the overall structure problem of my essay because I used the headings for the essay. After that, she read my essay literally and helps me to line out the problems of my essay.

In procedure description, students wrote about the process for setting up attendance at the service. It was present in 64 essays, but covered less text. One example:

I called English HELP and made a booking which was from 11am to 11:45am on $24^{\text {th }}$ of September 2010. I was told by email that I needed to go to G02. I have arrived there on time and met a teacher named Royce.

Purpose description was evident in one-third of texts, but was typically only one sentence long. Students explained why the service exists, as in: 'This service provides an opportunity for student to communicate with people from different countries'.

\section{Evaluation of the service experience}

Students used explicitly evaluative language to say something positive or negative about the service. However, there were many comments which could have been deemed 
evaluative in a contextual sense, but were not explicitly so, and therefore were not coded as such. For example, many students listed things they learned at the service, which had the rhetorical force within the essay of positive appraisal, although the writers used no semantically positive lexis. The results below should be read with this in mind: students were more positive about their service experiences than the figures indicate.

As Table 4 (above) showed, 36.9\% of actual text across the whole corpus consisted of evaluations of the services. Breaking this down into both positive and negative comments, the results were as follows:

\begin{tabular}{|l|c|c|c|}
\hline \multicolumn{1}{|c|}{ Type of evaluation } & $\begin{array}{c}\text { Number } \\
\text { of texts }\end{array}$ & Number of & Text coverage \% \\
\hline Positive & 73 & 247 & $28.8 \%$ \\
\hline Negative & 40 & 67 & $8.0 \%$ \\
\hline
\end{tabular}

Table 6. How the services were evaluated.

Every text $(n=73)$ contained at least one positive comment about the service. With 247 comments overall, this averages at 3.38 positive comments per text. Students' positive comments focused on a number of themes including: general praise (e.g. 'this service it's very convenient and useful for me'); the service staff (e.g. 'Kevin is a very nice teacher who used simple examples and language to help me to understand and inspired me to think'); learning outcomes (e.g. 'It can improve the students' English and get better grades'); and specific service content (e.g. 'I did not know about the referencing tool before and I found 
that extremely important for my future study').

Only 40 essays contained negative appraisals. At 67 comments overall, this averages at 1.68 per text, not including those with no negative comments. The most prominent misgiving concerned time: the service was not long enough or too infrequent. One student wrote, 'I think 45 minutes for each student per week is not enough for both speaking, listening, especially writing problems.' Another complaint was logistics: difficulty of access. As put by one student, 'The service should consider online consultations to be more flexible and help more students.' Poor content and/or sub-standard teaching were rarely mentioned.

Statements about learning gains

Students' comments about what they gained from the service accounted for $31.7 \%$ of text coverage with only one essay failing to mention learning gains. The types of gains could be classified into four categories: linguistic, scholastic, personal and professional.

\begin{tabular}{|l|c|c|}
\hline \multicolumn{1}{|c|}{ Type of learning } & $\begin{array}{c}\text { Number of } \\
\text { texts }\end{array}$ & $\begin{array}{c}\text { Text } \\
\text { coverage \% }\end{array}$ \\
\hline Linguistic & 52 & 20 \\
\hline Scholastic & 30 & 13.5 \\
\hline Personal & 16 & 2.6 \\
\hline Professional & 4 & 0.7 \\
\hline
\end{tabular}

Table 7 displays the prevalence of each type: 


\begin{tabular}{|l|c|c|}
\hline \multicolumn{1}{|c|}{ Type of learning gain } & $\begin{array}{c}\text { Number of } \\
\text { texts }\end{array}$ & Text \\
coverage \%
\end{tabular}

Table 7. Types of learning gains.

In $71 \%$ of essays $(n=52)$, students referred to improved language outcomes, accounting for $20 \%$ of all text coverage. 'Language outcomes' means that students either stated how the knowledge, skills, or use of service resources has led (or can lead) to second language development, or they outlined the steps they intend to take to facilitate their own language development, based on new knowledge learned from the service. The following is an example of a language learning gain: 'The knowledge I learned from this, was how to divide a long sentence into several more logical shorter sentences, in order to make the reader easier to understand'.

Scholastic gains refer to benefits derived from the service in relation to broader, nonlanguage-specific educational advancement. This category includes non-linguistic academic skill development such as referencing, mind mapping, and information literacy. These were mentioned in $41 \%$ of essays $(n=30)$, accounting for $13.5 \%$ of text coverage. In the following example a student refers to enhanced computer skills: 'The last thing I learnt was locking and 
unlocking documents. It will be very useful when you use your essay or report in University. It will protect your work so no one plagiarizes your own work.'

Some students (16 essays; $2.6 \%$ coverage) felt they benefited from the service in terms of personal growth, for example by making new friends or feeling more comfortable in the new culture. Improved confidence was a particularly common theme, e.g.: 'After the consultation time I felt more confident about my ideas'.

Professional benefits, or benefits for work after study, were rarely mentioned. One student stated that 'the teacher Charles Whitely taught us how to use sum up, vlookup, count if and other functions which are really useful in accounting career'. Overall, only a small number of students ( 4 essays, $0.7 \%$ coverage) mentioned the knowledge or skills obtained through the service as having applications in any future occupational context.

\section{Explanation of reason( $(s)$ for choosing the service}

Every text $(n=73$ ) included reasons for choosing the service (unsurprisingly, given this was an assignment instruction), accounting for $17.6 \%$ of text coverage. Students typically identified a personal problem or an aspiration which they hoped the service could address. As one student wrote, 'In order to improve my English communication skills and make many foreign friends, I joined Find Your Voice.'

\section{Statements of personal identity}

Although amounting to only $8.7 \%$ text coverage, $78 \%$ of the essays $(n=57)$ incorporated a proclamation of personal identity, typically as an opening statement. There were three groupings with which students affiliated: academic discipline, international 
student body, and first-year student body. As the quotes below demonstrate, students correlated their personal status with their developmental needs:

Discipline affiliation:

As an accounting student, computing skill is considered as an essential skill, since most works are done in Excel. However, due to the lack of practice, my computing skill needs to be improved.

International student affiliation:

Since it was my first time studying in an English speaking country, I had a lot of difficulties understanding my lectures and tutorials.

New student affiliation:

However, this is the first semester I spend in Griffith University, I am not familiar with the library search system, so I asked library academic services for help.

\section{Discussion}

Two services were more attractive than any other. $78 \%$ of participants attended either a one-to-one consultation about language issues or a study skills workshop. This suggests that the primary focus of the students was passing their courses. They accessed a service to improve an assignment or to acquire a study skill. This is supported by the analysis of what students wrote in regards to learning gains (

\begin{tabular}{|l|c|c|}
\hline \multicolumn{2}{|c|}{ Type of learning } & Number of \\
gain & texts & Text \\
\hline Linguistic & 52 & 20 \\
\hline
\end{tabular}




\begin{tabular}{|l|c|c|}
\hline Scholastic & 30 & 13.5 \\
\hline Personal & 16 & 2.6 \\
\hline Professional & 4 & 0.7 \\
\hline
\end{tabular}

Table 7): $20 \%$ of text coverage was devoted to language-related gains and $13.5 \%$ to scholastic gains, with little written about personal or professional benefits.

Students tended not to choose services with social benefits, such as a student exchange group (chosen by $8.4 \%$ of students) or a club (3.9\%). Reflecting this, only $2.6 \%$ of text coverage concerned personal gains from the service experience. A likely reason is that formal support services do not present a threat to face, since the student-instructor relationship is maintained in these activities. In contrast, sites of informal socialization involve establishing peer-to-peer relationships, and therefore significant emotional investment from the individual.

A positive finding is that two-thirds of students used the USRT to attend a service for the first time. This shows that the USRT succeeds in exposing students to new services. It is understandable that students would thus select services with the lowest threat to face since they are already leaving their comfort zone by choosing to participate in a consultation or workshop for the first time.

Another positive finding is that services seem to work well for a significant group of students: those who attend repeatedly without coercion. Three-quarters of the 'repeat users' group appear to be regular attendees of a particular service: $41.4 \%$ had used the service $3-5$ times before, $12.1 \%$ had used it 5-9 times and $15.5 \%$ had used it 10 or more times ( 


\begin{tabular}{|c|c|c|}
\hline & Number of students & Percentage \\
\hline Didn't answer & 4 & 6.9 \\
\hline $1-2$ times & 14 & 24.1 \\
\hline 3-5 times & 24 & 41.4 \\
\hline $5-9$ times & 7 & 12.1 \\
\hline $10+$ times & 9 & 15.5 \\
\hline Total & 58 & 100 \\
\hline
\end{tabular}

Table 3). A question that arises from this finding is whether first-time access (i.e. reluctance to take the first step) is a significant barrier to joining this group.

Reluctance cannot be attributed to dislike of the services, based on the evidence in this study. Analysis of the reflective texts indicates that once students attend a service, they typically have a good experience. Their evaluative writing about the services was consistently positive and even the negative comments were often backhanded compliments- for example, criticising the service for not offering more chances to attend. This is also supported by the number of existing users who repeatedly accessed the same service. While it is possible that students wrote what they believed their instructors wanted to hear (Macfarlane and Gourlay 2009), the students received no numerical grade for doing the assignment, so they knew that whatever they wrote, they would not lose any assessment points. Furthermore, the USRT instructions explicitly asked them to include 'a review of ... what areas were not satisfied by the service'. It seems that students had genuinely positive experiences and did not simply write what their instructors wanted to hear. 
Did the writing task stimulate meaningful reflection? The fact that evaluations of the services constituted $36.9 \%$ of text coverage and statements of learning gains accounted for $31.7 \%$ indicate that the students did engage in significant amounts of reflection. The majority of their writing was taken up with either critiquing the services or explaining what they got out of them. Both forms of reflection are important because they are two of the aims of the USRT: to have students identify services they like, and to have students understand what can be gained from services. These points are further supported by the fact that students were frequently able to articulate how services could meet their individual needs. Every text contained an explicit statement of why the service was selected (albeit unsurprisingly, since a directive to do so was included in the USRT instructions). More importantly, the fact that students devoted $17.6 \%$ of text coverage to this issue indicates that the reason for selecting a service was of interest to them. Most students identified some type of personal weakness, and this suggested that the USRT did foster reflective thought about individual needs and how services could meet them, although this may be an example of reflective writing encouraging the enactment of 'the penitent self' (Macfarlane and Gourlay 2009). It was significant that $78 \%$ of the texts $(n=57)$ addressed the issue of personal identity in relation to services, albeit in line with the USRT instructions to provide 'an overview of your academic situation'. Reflection can be particularly meaningful, according to Smith $(2011,213)$, when

it allows us to examine the uniqueness of our individual 'positionality' within social systems... This could mean looking at how we align ourselves with particular identities (mother, father, doctor, nurse, patient, etc.) or how these identities encourage us to act in certain ways.

In defining themselves as members of academic disciplines, beginners in higher education and/or outsiders to the local culture and language, the students aligned themselves with certain 'positionalities' within the university system, from which vantage points they could 
consider how particular services might address their needs.

In addition to these observations, there are some limitations and reservations to bear in mind. First, the assignment asks students to attend only one service on one occasion and compose 250 words. As both the experience and composition are short, major epiphanies are an unlikely immediate outcome. Second, it is generally not possible to capture the true nature of reflection in a written composition. The process of writing is intended as a catalyst for reflection and (possibly) change, but texts are not wholly reliable evidence of them. Authentic reflection may occur internally and result in action at a later time, with traces of it recorded on the page. Finally, the prevalence of simple description (text coverage $=38.5 \%$ ) may suggest that reflection was lacking. However, this result needs to be understood in relation to previous findings on reflective writing (e.g. Hatton and Smith 1995; Kember et al. 2008; Bell et al. 2011) which suggests that description is, in fact, a staple constituent of the genre. Boud, Keogh, and Walker $(1985,27)$ state that 'returning to experience' is an essential stage in reflection because when 'we witness the events again they become available for us to reconsider and examine afresh'. Whether recounting a dream, a crime or a lesson, it seems that describing events after the fact helps make sense of them.

\section{Conclusion}

The USRT requires only modest organisation, resources, and time investment: a onepage handout, some in-class explanation and the provision of formative feedback. In return, the benefits are significant. In this study, a large number of ISs were exposed to support services that they may otherwise have never attended. Students' written reflections indicated that the experiences were positive and meaningful. Connection with support services is also important for domestic (not just international) student development and future research could 
examine how a task such as this might benefit other students more broadly. Future iterations of the task could also tap into the knowledge and perspectives of those students who regularly use support services, perhaps reproducing their impressions in handouts or on screen, as material for class discussion. True success will only come when a majority of ISs adopt the behaviour of that group by taking regular advantage of the large number of extracurricular self-development opportunities that exist on campus. The USRT is only an initial, causative step towards change, and it is not known whether completing the assignment had any longtime effect on support service access; however it is a promising start.

\section{Acknowledgements}

The USRT was jointly designed by Griffith University's ELEC management team: Ben Fenton-Smith, Pamela Humphreys, Ana Lobo, Rowan Michael, and Ian Walkinshaw. We additionally thank Ian Walkinshaw and two anonymous reviewers for their advice on earlier drafts of this paper. We are also grateful to the office of Griffith University DVC (Academic) for providing financial and institutional support for this research project.

\section{References}

Australian Education International (AEI). 2010a. International graduate outcomes and employer perceptions. Canberra: Commonwealth of Australia, https://www.aei.gov.au/research/Publications/Documents/2010_International_Graduat e_Outcomes.pdf (accessed May 20, 2012).

Australian Education International (AEI). 2010b. International student survey 2010:

Overview report. Canberra: Commonwealth of Australia, https://aei.gov.au/research/Publications/Documents/2010_International_Student_Repo rt.pdf (accessed May 20, 2012). 
Astin, A. 1996. Involvement in learning revisited: Lessons we have learned. Journal of College Student Development 37, no. 2: 123-34.

Barrett-Lennard, S., and C. Bulsara. 2007. Perceptions and expectations of English requirements and support (PEERS). University of Western Australia, http://www.studentservices.uwa.edu.au/ss/learning/networking_smarter/llrs_projects? f=209724 (accessed May 20, 2012).

Bell, A., J. Kelton, N. McDonagh, R. Mladenovic, and K. Morrison. 2011. A critical evaluation of the usefulness of a coding scheme to categorise levels of reflective thinking. Assessment \& Evaluation in Higher Education 36, no.7: 797-815.

Benzie, H.J. 2010. Graduating as a 'Native Speaker': International students and English language proficiency in higher education. Higher Education Research \& Development 29, no. 4: 447-59.

Birrell, B. 2006. Implications of low English standards among overseas students at Australian universities. People and Place 14, no. 4: 53-64.

Boud, D., R. Keogh, and D. Walker. 1985. Promoting reflection in learning: a model. In Reflection: Turning experience into learning, ed. D. Boud, R. Keogh and D. Walker, 18-40. London: Kogan Lane.

Clarkeburn, H., and K. Kettula. 2011. Fairness and using reflective journals in assessment. Teaching in Higher Education. (iFirst), DOI: 10.1080/13562517.2011.641000.

Department of Education, Employment and Workplace Relations (DEEWR). 2009. Good practice principles for English language proficiency for international students in Australian universities. Canberra: Commonwealth of Australia, http://www.deewr.gov.au/highereducation/publications/pages/goodpracticeprinciples. aspx (accessed May 20, 2012).

Dewey, J. 1910. How We Think. Boston: D.C. Heath.

Dyment, J.E., and T.S. O'Connell. 2011. Assessing the quality of reflection in student journals: A review of the research. Teaching in Higher Education 16, no. 1: 81-97.

Ewart, H. 2007. Unis 'demanding' foreign students be passed. ABC Television 7.30 Report, February 20, http://www.abc.net.au/7.30/content/2007/s1852629.htm (accessed May 20, 2012).

Gersham, R., and V. Clayton. 2011. Community Connections: A programme to enhance domestic and international students' educational experience. Journal of Higher Education Policy Management 33, no. 4: 363-74. 
Hatton, N., and D. Smith. 1995. Reflection in teacher education: Towards definition and implementation. Teaching and Teacher Education 11, no. 1: 33-49.

Healy, G., and A. Trounson. 2010. Universities told to boost English programs. The Australian, February 10, http://www.theaustralian.com.au/highereducation/universities-told-to-boost-english-programs/story-e6frgcjx-1225828473695 (accessed May 20, 2012).

Hyland, K. 2006. English for academic purposes: An advanced resource book. London: Routledge.

Ixer, G. 1999. There's no such thing as reflection. British Journal of Social Work 29: 513-27.

Kember, D., A. Jones, A. Loke, J. Mckay, K. Sinclair, H. Tse, C. Webb, F. Wong, M. Wong, and E. Yeung. 1999. Determining the level of reflective thinking from students' written journals using a coding scheme based on the work of Mezirow. International Journal of Lifelong Education 18, no. 1: 18-30.

Kember, D., J. McKay, K. Sinclair, and F.K.Y. Wong. 2008. A four-category scheme for coding and assessing the level of reflection in written work. Assessment \& Evaluation in Higher Education 33, no. 4: 369-79.

Loughran, J.J. 1996. Developing reflective practice: Learning about teaching and learning through modeling. Washington, DC: Falmer Press.

Macfarlane, B., and L. Gourlay. 2009. The reflection game: Enacting the penitent self. Teaching in Higher Education 14, no. 4: 455-9.

Marginson, S., C. Nyland, E. Sawir, and H. Forbes-Mewett. 2010. International student security. Cambridge: Cambridge University Press.

Moon, J. 2006. Learning journals: A handbook for reflective practice and professional development. London: Routledge.

Peat, M., J. Dalziel, and A.M. Grant. 2001. Enhancing the first year student experience by facilitating the development of peer networks through a one-day workshop. Higher Education Research and Development 20, no. 2: 199-215.

Prebble, T., H. Hargraves, L. Leach, K. Naidoo, G. Suddaby, and N. Zepke. 2004. Impact of student support services and academic development programmes on student outcomes in undergraduate tertiary study: A Synthesis of the research. New Zealand: Ministry of Education, http://www.educationcounts.govt.nz/_data/assets/pdf_file/0013/7321/ugradstudentou tcomes.pdf (accessed May 20, 2012). 
Rochecouste, J., R. Oliver, D. Mulligan, and M. Davies. 2010. Addressing the ongoing English language growth of international students. Strawberry Hills, NSW: Office for Learning and Teaching, http://www.olt.gov.au/resource-addressing-ongoingenglish-language-growth-international-students-monash-2010 (accessed May 20, 2012).

Rogers, R. 2001. Reflection in higher education: A concept analysis. Innovative Higher Education 26, no. 1: 37-57.

Ryan, M. 2011. Improving reflective writing in higher education: A social semiotic perspective. Teaching in Higher Education 16, no. 1: 99-111.

Saenz, T., G. Marcoulides, E. Junn, and R. Young. 1999. The relationship between college experience and academic performance of minority students. The International Journal of Educational Management 13, no. 4: 199-207.

Seibert, K.W., and M.W. Daudelin. 1999. The role of reflection in managerial learning: Theory, research, and practice. Westport, CT: Quorum.

Sinkovics, R., and Alfoldi, E. 2012. Progressive focussing and trustworthiness in qualitative research: The enabling role of computer-assisted qualitative data analysis software. Management International Review 52, no 6: 817-45.

Smith, E. 2011. Teaching critical reflection. Teaching in Higher Education 16, no. 2: 211-23.

Smith, R. 2008. Learner autonomy. ELT Journal 62: 395-7.

Stallman, H.M. 2011. Embedding resilience within the tertiary curriculum: A feasibility study. Higher Education Research \& Development 30, no. 2: 121-33.

Stewart, S., and B. Richardson. 2000. Reflection and its place in the curriculum on an undergraduate course: Should it be assessed? Assessment \& Evaluation in Higher Education 25, no. 4: 369-80.

Walsh, E. 2010. A model of research group microclimate: Environmental and cultural factors affecting the experiences of overseas research students in the UK. Studies in Higher Education 35, no. 5: 545-60. 


\section{Appendix 1. The University Service Reflection Task}

\section{แ)}

5902 LAL Language \& Communication

for Health

\section{PORTFOLIO: UNIVERSITY SERVICE REFLECTION TASK}

- Attend one of the services below and write a reflection on your experience.

- Note that some services are not offered after Week 6 in the semester, and that almost all of them will require advanced bookings to attend. It is your responsibility to make arrangements to attend the service of choice as early as possible. Refer to the relevant website below for further information regarding service dates.

- The selected service must be conducted in English and must not have been specifically created for members of your nationality.

- The reflection is to be 250 words (+/- 10\%). A word count should be in brackets at the end of the reflection.

- The reflection is to be typed (1.5 line spacing) and in 12 point Arial font.

- The reflection is to be submitted with your completed portfolio in Week 11. If this task is not submitted, $10 \%$ will be deducted from the final portfolio score.

- The reflection should include the following parts:

$>$ Introduction

This includes an overview of your academic situation, the service chosen, and your reason for choosing this particular service.

$>$ Body

This includes a description of the service (eg. where, when, who, and what was involved) and a review of the service (eg. what was useful for you, how you intend to apply the knowledge learned, and what areas were not satisfied by the service).

$>$ Conclusion

This includes your overall appraisal of the service and suggestions for future personal development in this area.

- Library Learning Services (academic, computing, and library research services):

$>$ http://www.griffith.edu.au/library/workshops-training

$>$ http://www.griffith.edu.au/ data/assets/pdf file/0003/109992/ls-guide-draft-2010website.pdf

- StudentLinx (social networking service):

$>$ http://www.griffith.edu.au/griffith-english-language-institute/university-initiatives/student-linx

- EnglishHELP (English Higher Education Language Program):

$>$ http://www.griffith.edu.au/griffith-english-language-institute/university-initiatives/englishhelp

- Careers and Employment (job search seminars and career counselling appointments)

$>$ https://intranet.secure.griffith.edu.au/community-welfare-recreation/careersemployment/assistance-with-job-search/job-search-seminars

$>$ https://intranet.secure.griffith.edu.au/community-welfare-recreation/find-careerdirection/? $a=78458$

- Griffith University Clubs (professional, political, recreational, social, religious, sporting etc.): $>$ http://www.griffith.edu.au/clubs/clubs-a-to-z 


\section{Appendix 2. Questionnaire}

1. Which of the following university services did you select for the 'University Service Reflection Task' that you completed for the 5901 LAL portfolio? Place a check mark in one box.

\begin{tabular}{|l|l|}
\hline University Service & X \\
\hline Library Learning Services (academic, computing, and library research & \\
\hline Student Linx (social networking service) & \\
\hline English HELP (English language support service) & \\
\hline Find Your Voice (intercultural communication workshops) & \\
\hline Careers and Employment (job search seminars and career counselling & \\
\hline appointments) & \\
\hline Griffith University Clubs (professional, political, recreational, social, & \\
religious, sporting etc.) & \\
\hline I didn't do the activity & \\
\hline
\end{tabular}

2. Was this the first time you had tried this service? YES $\mathrm{NO}$

(If you answered YES, do not answer Q.3)

3. How many times have you attended this service (not including the time you attended for the portfolio task)? Place a check mark in one box.

\begin{tabular}{|l|l|l|l|l|l|l|l|}
\hline $1-2$ & & $3-5$ & & $5-9$ & & $10+$ & \\
\hline
\end{tabular}

Thank you for completing this survey. 